\title{
PENGELOLAAN ZAKAT DI INDONESIA
}

\begin{abstract}
Ahdiyat Agus Susila*
Abstract: Zakat is one of worship in Islam with personal, social and economic dimension. In an economic review, zakat is the main instrument of the state's fiscal policy to distribute equitable wealth and prosperity. Therefore, management management mechanisms should receive serious attention. Zakat managers must be able to carry out the mandate of realizing the potential of extraordinary zakat, especially in Indonesia. Based on a study conducted Baznaz in collaboration with IPB and Islamic Development Bank in 2011, the potential of zakat acceptance of all Muslims in Indonesia for Rp. 217 trillion rupiah.
\end{abstract}

Keywords: Zakat, and Indonesia

\section{A. Pendahuluan}

Zakat berasal dari bentukan kata zaka yang berarti 'suci', 'baik', 'berkah', 'tumbuh', dan 'berkembang'. Senada dengan Yusuf Qardhawi bahwa kata dasar zaka berarti bertambah dan tumbuh, sehingga bisa dikatakan bahwa "tanaman itu zaka", artinya tanaman itu tumbuh. Menurut terminologi syariat (istilah), zakat adalah nama bagi sejumlah harta tertentu yang diwajibkan oleh Allah untuk dikeluarkan zakat dan diberikan kepada yang berhak menerimanya dengan persyaratan tertentu pula. Kaitan antara makna secara bahasa dan istilah ini berkaitan erat sekali, yaitu bahwa setiap harta yang sudah dikeluarkan zakatnya akan menjadi suci, bersih, baik, berkah tumbuh, dan berkembang (at-Taubah: 103 dan Ar-Rum: 39). ${ }^{1}$

Zakat adalah salah satu ibadah dalam Islam yang berdimensi spritual personal, sosial dan ekonomi. Dalam tinjauan ekonomi, zakat adalah instrumen utama kebijakan fiskal negara guna mendistribusikan kekayaan dan kesejahteraan yang berkeadilan. ${ }^{2}$ Oleh karena itu, mekanisme manajemen pengelolaan harus mendapat perhatian serius. Pengelola zakat harus mampu mengemban amanah mewujudkan potensi zakat yang luar biasa, terutama di Indonesia. Berdasarkan studi yang dilakukan Baznaz bekerjasama dengan IPB dan Islamic Development

\footnotetext{
* Dosen tetap Institut Ilmu Keislmana Zainul Hasan genggong Kraksaan Probolinggo

${ }^{1}$ Didin Hafidhuddin, Panduan Praktis Tentang Zakat, Infak, dan Sedekah. Jakarta: Gema Insani, 1998, hlm. 13

${ }^{2}$ Dr. F. R. Faridi, A Theory of Fiscal Policy in an Islamic State, Dalam Zianuddin Ahmad, et al., Fiscal Policy and Resource Allocation in Islam, Jeddah: International Centre for Research in Islamic Economics King Abdulaziz University, Islamabad: Institute of Policy Studies, 1983, hlm. 25.
} 
Bank pada tahun 2011 lalu, potensi penerimaan zakat dari seluruh umat muslim di Indonesia sebesar Rp. 217 triliun rupiah. $^{3}$

Di tengah besarnya potensi tersebut, faktanya saat ini peran organisasi pengelola Zakat (OPZ) dan negara dalam menghimpun zakat masih belum maksimal. Hal ini ditunjukkan minimnya realisasi pengumpulan dana zakat yang mencapai 1,7 T (2011), 2,73 T (2012), 3,2 T (2014), 5,12 T (2016), 6 T (2017). Angka kemiskinan juga masih tinggi. Idealnya, jumlah umat Islam yang mayoritas dapat dijadikan kekuatan untuk melakukan perubahan di bidang ekonomi untuk mencapai kesejahtraan umat. Padahal, jumlah umat Islam yang sangat besar adalah potensi yang semestinya menjadi kekuatan utama dalam pengentasan kemiskinan. ${ }^{4}$

Banyak faktor yang menyebabkanya, diantaranya masih adanya paradigma lama dan cara-cara tradisional dalam mengelola dan mengembangkan harta zakat. Hal tersebut dapat dilihat dari perjalanan pengelolaan zakat di Indonesia. Dalam perjalanan yang telah melewati masa berabad-abad, praktik pengelolaan zakat masih dilakukan dengan sangat sederhana. Zakat yang populer dikalangan kaum muslimin hanyalah zakat fitrah. Penyaluran zakat ini diberikan kepada ustadz, kyai, atau ajengan disekitar tempat tinggal mereka. Selain itu, zakat juga disalurkan melalui pesantren dan masjid atau lembaga sosial Islam seperti panti anak yatim, dan tidak sedikit pula diserahkan langsung kepada fakir miskin. ${ }^{5}$

Pengelolaan zakat yang profesional, diharapkan pendistribusiannya lebih produktif, pemberian pinjaman modal misalnya, dalam rangaka peningkatan prekonomia masyarakat. Persoalan kemudian adalah bagaimana harta zakat itu dapat dikumpulkan untuk kemudian didistribusikan dan didayagunakan untuk kepentingan penerima zakat (mustahik). Para pemerhati zakat sepakat bahwa untuk dapat mengumpulkan, mendistribusikan, dan mendayagunakan zakat secara optimal, maka zakat harus dikelola melalui lembaga.

\section{B. Pembahasan}

\section{Peran Negara dalam Pengelolaan Zakat}

Secara umum fase pengelolaan zakat di Indonesia di Indonesia dapat di bagi menjadi empat tahapan. Pertama, Pengelolaan Zakat Masa Penjajahan. Pada masa ini pelaksanaan ajaran agama Islam (termaksud zakat) diatur dalam Ordonantie pemerintah Hindia belanda Nomor 6200 tanggal 28 februari 1905.

Dalam pengaturan ini pemerintah tidak mencampuri masalah pengelolaan

\footnotetext{
${ }^{3}$ Muhammad Firdaus, et.all, Economic Estimation and Determinations of Zakat Potential in Indonesia, IRTI.

${ }^{4}$ Departemen Agama RI Dirjen Bimas Islam Direktorat Pemberdayaan Zakat, Panduan Organisasi Pengelola Zakat, Jakarta: Depag, 2008, hlm. 10.

${ }^{5}$ Ibid
} 
zakat dan menyerahkan sepenuhnya kepada umat Islam dan bentuk pelaksaannya sesuai dengan syariat islam. ${ }^{6}$

Kedua, Pengelolaan Zakat Awal Kemerdekaan. Pada masa ini pengelolaan zakat juga tidak diatur pemerintah dan masih menjadi urusan masyarakat. Kemudian pada tahun 1951 barulah kementrian agama mengeluarkan surat edaran nomor: A/VII/17367, tanggal 8 desember 1951 tentang pelaksanaan zakat fitrah. Pada tahun 1964, kementrian agama menyusun Rancangan Undang-Undang Tentang Pelaksanaan Zakat dan Rencana Peraturan Pemerintah Pengaganti Undang-Undang tentang Pelaksanaa Pengumpulan dan Pembagian Zakat Serta Pembentukan Baitul Maal, tetapi kedua perangkat peraturan tersebut belum sempat diajukan kepada DPR maupun kepada Presiden. ${ }^{7}$

Ketiga, Pengelolaan Zakat di Masa Orde Baru. Pada fase ini, kekhawatiran terhadap Islam ideologis memaksa pemerintah untuk tidak terlibat dalam urusan zakat. Bahkan secara struktural pun pemerintah tidak tegas memberikan dukungan legal forrmal. Zakat masih dikumpulkan dengan cara konvensional dan musiman sehingga zakat tidak memberikan dampak yang berarti. Perlakuan orde baru disebabkan oleh tekanan psikologis yang kuat karena pengalaman politik persaingan antara nasional, sekuler dan islam. Dan sejak tahun 1968 Presiden Soeharto hanya memberikan ruang pengelolaan zakat melelui Keppres no.7/PRIN/10/1968. Aturan ini memberikan dorongan pada Pemda-pemda didaerah, seperti DKI Jakarta, Kaltim, Sumbar, Aceh untuk mendirikan lembaga zakta yang langsung dikontrol oleh pemerintah daerah. ${ }^{8}$

Keempat, Pengelolaan Zakat di Era Reformasi. Momentum sejarah dunia zakat Indonesia terjadi pada tahun 1999, tepat setelah turunnya Presiden Soeharto. Sejak tahun 1999, zakat secara resmi masuk kedalam ranah hukum positif di Indonesia dengan keluarnya UU No.38/1999 tenteng pengelolaan zakat. berdasakan UU ini, zakat dapat dikelola baik oleh lembaga amil bentukan pemerintah yaitu Badan Amil zakat (BAZ) maupun oleh lembaga amil bentukan masyarakat yaitu lembaga amil zakat (LAZ). Lahirnya Undangundang ini diikuti dengan dikeluarkannya keputusan menteri Agama Nomor 581 tahun 1999 tentang Pelaksanaan Undang-Undang nomor 38 tahun 1999 serta dikeluarkan pula keputusan Direktorat Jendral Bimas Islam dan Urusan Haji Nomor D-291 Tahun 2000 tentang pedoman teknis pengelolaan zakat. ${ }^{9}$

6 Tim Penyusun, Panduan Organisasi Pengelolaan Zakat, Jakarta: Departemen Agama RI, Thn. 2008, hlm. 6.

${ }^{7}$ Ibid

${ }^{8}$ Ibid

${ }^{9}$ Tim Penyusun, Menggagas Arsitektur zakat Indonesia, Ciputat :IMZ, 2011 hlm.76 
Berdasarkan Undang-undang Nomor 38 tahun 1999 ini, pengelolaan zakat dilakukan oleh Badan Amil Zakat (BAZ) yang dibentuk oleh Pemerintah yang terdiri dari masyarakat dan unsur pemerintah untuk tingkat kewilayahan dan Lembaga Amil Zakat (LAZ) yang dibentuk dan dikelola oleh masyarakat yang terhimpun dalam berbagai ormas (organisasi masyarakat) Islam, yayasan dan institusi lainnya.

Dalam Undang-undang Nomor 38 tahun 1999 dijelaskan prinsip pengelolaan zakat secara profesional dan bertanggungjawab yang dilakukan oleh masyarakat bersama pemerintah. Pemerintah dalam hal ini berkewajiban memberikan perlindungan, pembinaan, dan pelayanan kepada muzakki, mustahiq, dn pengelola zakat. Pengelolaan zakat dilakukan oleh Badan Amil Zakat yang dibentuk oleh pemerintah, tetapi kedudukan formal badan itu sendiri tidak terlalu jauh berbeda dibanding masa lalu. Amil zakat tidak memiliki power untuk menyuruh orang membayar zakat. Mereka tidak diregistrasi dan diatur oleh pemerintah seperti halnya petugas pajak guna mewujudkan masyarakat yang peduli bahwa zakat adalah kewajiban.

Sebagai konsekuensi Undang-undang Zakat, pemerintah (tingkat pusat sampai daerah) wajib memfasilitasi terbentuknya lembaga pengelola zakat, yaitu Badan Amil Zakat Nasional (Baznas) untuk tingkat Pusat dan Badan Amil Zakat Daerah (BAZDA) untuk tingkat Daerah. BAZNAS dibentuk berdasarkan Kepres Nomor 8 /2001, tanggal 17 Januari 2001. Ruang lingkup BAZNAS berskala Nasional yaitu unit pengumpul Zakat (UPZ) di Departemen, BUMN, Konsulat Jenderal dan Badan Usaha Milim Swasta berskala nasional, sedangkan BAZDA ruang lingkup kerjanya di wilayah propinsi tersebut.

Sesuai undang-undang Pengelolaan Zakat, hubungan BAZNAS dengan Badan amil zakat yang lain bersifat koordinatif, konsultatif, dan informatif. BAZNAS dan BAZDA-BAZDA bekerjasama dengan Lembaga Amil Zakat (LAZ), baik yang bersifat nasional maupun daerah. Sehingga dengan demikian diharapkan bisa terbangun sebuah sitem zakat Nasional yang baku, yan bisa diaplikasikan oleh semua pengelola zakat.

Dalam menjalankan program kerjanya, BAZNAS mengunakan konsep sinergi, yaitu untuk pengumpulan ZIS (Zakat, Infaq, Shadaqah) menggunakan hubungan kerjasama dengan unit pengumpul zakat (UPZ) di Departemen, BUMN, Konjen, dan dengan lembaga amil zakat lainnya. Pola kerjasama itu disebut dengan UPZ Mitra BAZNAS. Sedangkan untuk penyalurannya, BAZNAS juga menggunakan pola sinergi dengaLembaga Amil Zakat lainnya, yang disebut sebagai unit Salur Zakat (USZ) Mitra BAZNAS.

Dengan demikian, maka Undang-Undang Nomor 38 Tahun 1999 tentang Pengelolaan Zakat telah melahirkan paradigma baru pegelolaan zakat 
yang antara lain mengatur bahwa pengelolaan zakat dilakukan oleh satu wadah, yaitu Badan Amil Zakat (BAZ) yang dibentuk oleh pemerintah bersama masyarakat dan Lembaga Amil Zakat (LAZ) yang sepenuhnya dibentuk oleh masyarakat yang terhimpun dalam ormas maupun yayasanyayasan.

Dengan lahirnya paradigma baru ini, maka semua Badan Amil Zakat harus segera menyesuaikan diri dengan amanat Undang-Undang yakni pembentukannya berdasarkan kewilayahan pemerintah Negara mulai dari tingkat nasional, provinsi, kabupaten/kota dan kecamatan. Sedangkan untuk desa/kelurahan, mesjid, lembaga pendidikan dan lain-lain dibentuk unit pengumpul zakat. Sementara sebagai Lembaga Amil Zakat, sesuai amanat undang-undang tersebut, diharuskan mendapat pengukuhan dari pemerintah sebagai wujud peminaan, perlindungan dan pengawasan yang harus diberikan pemerintah. Karena itu bagi Lembaga Amil Zakat yang telah terbentuk di sejumlah Ormas Islam, yayasan atau LSM (Lembaga Swadaya Masyarakat), dapat mengajukan permohonan pengukuhan kepada pemerintah setelah memenuhi sejumlah persyaratan yang ditentukan.

Dalam rangka melaksanakan pengelolaan zakat sesuai dengan amanat undang-undang Nomor 38 tahun 1999, pemerintah pada tahun 2001 membentuk Badan Amil Zakat Nasional (BAZNAS) dengan Keputusan Presiden. Di setiap daerah juga ditetapkan pembentukan Badan Amil Zakat Provinsi, Badan Amil Zakat Kabupaten/Kota hingga Badan Amil Zakat Kecamatan. Pemerintah juga mengukuhkan keberadaan Lembaga Amil Zakat (LAZ) yang didirikan oleh masyarakat. LAZ tersebut melakukan kegiatan pengelolaan zakat sama seperti yang dilakukan oleh Badan Amil Zakat. Pembentukan Badan Amil Zakat di tingkat nasional dan daerah mengantikan pengelolaan zakat oleh BAZIS (Badan Amil Zakat, Infaq dan Shadaqah) yang sudah berjalan dihampir semua daerah. ${ }^{10}$

\section{Peran Zakat dalam Pemberdayaan Masyarakat}

Manajemen penghimpunan dana zakat sudah mulai tertata dengan baik. Pasca pemberlakuan Undang-Undang RI Nomor 38 tahun 1999 tentang Pengelolaan Zakat. Eksistensi institusi zakat, baik yang dibentuk oleh pemerintah atau yang lahir dari inisiatif masyarakat yang kian penting dan strategis. $^{11}$ Kegiatan penghimpunan dana zakat melalui OPZ (Organisasi Pengelolaan zakat) adalah melakukan beberapa kegiatan sebagai berikut: ${ }^{12}$

\footnotetext{
${ }^{10} \mathrm{https}$;//aliboron.wordpress.com, diakses tanggal 7 Juni 2018

${ }^{11}$ Didin Hafidhuddin, Zakat dalam Perekonomian Modern. Jakarta: Gema Insani, 2002, hlm. 130

12 Departemen Agama RI, Panduan Organisasi Pengelolaan Zakat, Jakarta: Direktorat Pemberdayaan Zakat, 2008, hlm. 70
} 
a. Melakukan sosialisasi kewajiban ZIS di wilayahnya.

b. Memberikan Pelayanan Kepada Muzaki.

c. Mengumpulkan dana zakat dan non zakat.

d. Mengadministrasikan pengumpulan dana ZIS.

e. Mengelola data base muzaki.

f. Memberikan laporan kegiatan pengumpulan ZIS di OPZ

Dalam pengelolaan zakat penyaluran merupakan masalah terpenting dan utama. Hal ini dapat kita lihat dari sistematika penulisan Al-Qur'an dimana perintah penyaluran zakat (At-Taubah: 60) lebih didahulukan dari ayat pengumpulan zakat (QS. At-Taubah: 103).

Zakat adalah untuk delapan asnaf, bahkan dapat melebar ketika terjadi keadaan darurat. Dengan demikian, penyaluran zakat tidak menumpuk pada satu orang tertentu, tetapi tersebar kepada semua asnaf secara adil dan merata. Pembayaran zakat pada asnaf tertentu, berakibat gemuknya satu asnaf, sementara asnaf yang lain kekurusan. Padahal semua asnaf memiliki hak yang sama untuk mendapatkan zakat. Zakat dibagi secara prioritas sesuai kebutuhan yang paling mendesak. Al-Qur'an memang menyebutkan delapan asnaf, tetapi tidak menyebutkan harus bagi rata. Di dalamnya ada ruang gerak untuk berkreasi, sehingga lebih fokus dalam pencapaian tujuan penetapan kewajiban zakat.

Dari sisi penyaluran UU yang baru menggunakan dua istilah, yaitu pendistribusian dan pendayagunaan. Pendayagunaan digunakan secara khusus sebagai istilah untuk penyaluran zakat secara produktif, dengan tujuan untuk meningkatkan kualiats ummat. ${ }^{13}$

Ada dua bentuk dana penyaluran zakat antara lain:

a. Bentuk sesaat, dalam hal ini berarti zakat diberikan kepada seseorang satu kali atau sesaat saja. Dalam hal ini juga berarti bahwa penyaluran kepada mustahik tidak disertai target kemandirian ekonomi dalam diri mustahik. Hal ini dikarenakan mustahik yang bersangkutan "tidak mungkin lagi mandiri”, seperti orang tua yang sudah jompo dan cacat.

b. Bentuk pemberdayaan, merupakan penyaluran zakat yang disertai target merubah keadaan penerima dari kondisi kategori mustahik menjadi muzakki. Target ini adalah target besar yang tidak dapat mudah dan dengan waktu yang singkat. Untuk itu, penyaluran zakat harus disertai dengan pemahaman yang utuh terhadap permasalahan yang ada pada penerima. Apabila permasalahannya adalah permasalahan kemiskinan, maka harus diketahui penyebab kemiskinan

\footnotetext{
${ }^{13}$ Tim Peneliti IMZ, Indonesia Zakat Development Report 2012. Jakarta: IMZ, 2012, hlm
} 231. 
tersebut sehingga dapat mencari solusi yang tepat demi tercapainya target yang telah dicanangkan. ${ }^{14}$

Penyaluran dana zakat dalam paradigma yang baru adalah penyaluran kearah bentuk-bentuk yang produktif, tanpa meninggalkan bentuk konsumtif. Maksudnya, penyaluran dana zakat diperuntukan juga bagi program jangka panjang dan program pemberdayaan.

Program pendayagunaan zakat untuk pembiayaan produktif membutuhkan pendampingan. Program seperti ini tidak boleh dilepas oleh OPZ tanpa didampingi terlebih dahulu untuk beberapa waktu. Bahkan pendampingan perlu terus dilakukan selama program tersebut bergulir untuk mengantisipasi kurang efektif program tersebut berjalan. Metode pendampingan diterapkan dalam mayoritas program sesuai kondisi dan situasi kelompok sasaran yang dihadapi. Fungsi pendamping sangat penting, terutama dalam membina dan mengarahkan kegiatan kelompok sasaran. Pendamping bertugas mengarahkan proses pembentukan dan penyelenggaraan kelompok sebagai fasilitator (pemandu), komunikator (penghubung) maupun dinamisator (penggerak).

Dalam konteks pendampingan masyarakat, ada tiga peran dan tugas yang menjadi tanggung jawab OPZ, yakni: 1). sebagai motivator, 2). sebagai komunikator dan 3). sebagai fasilitator. Sebagai motivator, pendamping berperan sebagai pendorong motivasi masyarakat mau menjalankan suatu program. Peran komunikator dijalankan pendamping untuk memperlancar jalinan komunikasi antar pemangku jabatan. Terakhir sebagai fasilitator, pndamping harus piawai memandu semua pihak agar tetap berada pada jalur bergulirnya suatu program. ${ }^{15}$

Zakat pada hakikatnya adalah mengubah mustahiq menjadi muzaki. Zakat harus bermanfaat ganda dan bersifat jangka panjang. Penyaluran zakat harus dapat mengentaskan seseorang dari kemiskinannya, sehingga pada saatnya, yang bersangkutan dapat berubah dari mustahik menjadi muzakki atau minimal mutashaddiq. Penerima zakat, bukan duduk berpangku tangan, bergoyang kaki, setelah menerima zakat, tetapi justru semakin terdorong untuk bekerja keras dengan uang zakat yang diterimanya.

Zakat harus mendidik masyarakat keluar dari kemiskinan yang menyelimutinya. Penerima zakat, setelah menerima zakat, harus lebih terpacu dan termotivasi untuk berkarya mengentaskan dirinya dari kemiskinan. Hal ini sebagaimana yang dilakukan oleh seorang sahabat Nabi yang mempunyai keahlian mengumpul kayu api. Si pengumpul kayu api tersebut, menggunakan kampak yang diberikan Nabi kepadanya secara sungguh-sungguh, sehingga

${ }^{14}$ Lili Badriadi et.al, Zakat dan Wirausaha. Jakarta: CED, 2005, hlm. 25.

15 Tim Peneliti IMZ, Indonesia Zakat \& Development Report 2012, hlm. 154 
dapat memenuhi kebutuhan keluarganya dan bahkan dapat menyimpan uang sisa.

Peranan zakat bukanlah sekedar memberikan beberapa uang atau beberapa liter beras yang cukup untuk menghidupi seorang penerima zakat dalam beberapa hari atau beberapa pekan. Sebenarnya peranan zakat itu terletak pada bagaimana seorang penerima mampu menghidupi dirinya sendiri dengan kemampuan yang dimilikinya. Dan, memiliki penghasilan tetap yang mencukupi kehidupannya, sehingga ia tidak perlu bergantung kepada bantuan orang lain. Setiap orang yang memiliki satu keterampilan khusus ataupun mempunyai bakat berdagang, berhak untuk mendapatkan bagian dari zakat yang ada, agar ia mampu menjalankan profesinya. Pada akhirnya, ia mampu mendapatkan penghasilan tetap yang dapat mencukupi kebutuhan hidupnya. Bahkan mencukupi kebutuhan keluarganya dengan teratur dan untuk selamanya. Sedangkan bagi seseorang yang lemah dan tidak mampu untuk menjalankan keterampilan, profesi, ataupun bekerja untuk mencari nafkah bagi kehidupannya, Islam telah menetapkna suatu hukum yang khusus. ${ }^{16}$

Secara teoritis, beberapa pendapat mengemukakan bahwa terdapat sejumlah faktor utama yang menentukan suatu usaha produktif dari kelompok masyarakat dapat tumbuh dan berkembang secara efektif, yaitu:

a. modal kerja,

b. teknologi tepat guna,

c. model manajemen usaha,

d. pengembangan keterampilan menyangkut pemanfaatan modal kerja, teknologi dan manajemen usaha, dan e) etos kerja, semangat, disiplin kerja, dan sebagainya. ${ }^{17}$

Dari faktor-faktor tersebut, faktor modal kerja merupakan yang paling utama. Tanpa modal usaha yang memadai, setiap usaha akan mengalami kesulitan dalam melakukan proses usahanya, baik memproduksi barangbarang maupun melakukan transaksi jual-beli barang karena hal demikian tidak mungkin dilakukan tanpa adanya modal usaha. Proses ini mencakup tiga tahap yang saling berkaitan yang meliputi:

a. keberadaan tabungan nyata dan kenaikannya,

b. keberadaan lembaga keuangan dan kredit untuk menggalakkan tabungan menyalurkan kearah yang dikehendaki, dan

c. mempergunakan tabungan untuk investasi barang modal.

Pada dasarnya konsep pemberdayaan muncul karena adanya kegagalan dan harapan. Kegagalan yang dimaksud adalah gagalnya model-model

${ }^{16}$ Yusuf Qaradhawi, Spektrum Zakat Dalam Membangun Ekonomi Kerakyatan, Jakarta: Zikrul Hakim, 2005. hlm. 8

${ }^{17}$ www.damandiri.or.id diakses 10 Juni 2018 
pembangunan ekonomi dalam menanggulangi masalah kemiskinan dan lingkungan yang berkelanjutan. Sedangkan harapan, muncul karena adanya alternatif pembangunan yang memasukkan nilai-nilai demokrasi, persamaan gender, dan pertumbuhan ekonomi yang memadai. Dengan model pemberdayaan, pengelolaan zakat diharapkan mampu mengentaskan kemiskinan secara signifikan. ${ }^{18}$

\section{Penutup}

Dalam Undang-Undang RI Nomor 38 tahun 1999 tentang Pengelolaan Zakat Bab III pasal 6 dan pasal 7 menyatakan bahwa lembaga pengelola zakat di Indonesia terdiri dari dua macam, yaitu: Badan Amil Zakat (BAZ) dan Lembaga Amil Zakat (LAZ). Pembentukan institusi zakat tersebut bertujuan untuk membantu pemerintah dalam pengentasan kemiskinan di Indonesia.

UU No.38 Tahun 1999 Tentang Pengelolaan Zakat sudah direvisi dengan UU No. 23 tahun 2011 Tentang Pengelolaan Zakat. Setelah disahkannya UU Pengelolaan Zakat tersebut Indonesia telah memasuki tahap institusionalisasi pengelolaan zakat dalam wilayah formal kenegaraan, meskipun masih sangat terbatas. Lembaga-lembaga pengelola zakat mulai berkembang, termasuk pendirian lembaga zakat yang dikelola oleh pemerintah, yaitu BAZNAS (Badan Amil Zakat Nasional), BAZDA (Badan Amil Zakat Daerah) dan LAZ (Lembaga Amil Zakat) yang dikelola masyarakat dengan manajemen yang lebih baik dan modern.

Pengelolaan zakat yang profesional, diharapkan pendistribusiannya lebih produktif, pemberian pinjaman modal misalnya, dalam rangaka peningkatan prekonomia masyarakat. Persoalan kemudian adalah bagaimana harta zakat itu dapat dikumpulkan untuk kemudian didistribusikan dan didayagunakan untuk kepentingan penerima zakat (mustahik).

Zakat pada hakikatnya adalah mengubah mustahiq menjadi muzaki. Zakat harus bermanfaat ganda dan bersifat jangka panjang. Penyaluran zakat harus dapat mengentaskan seseorang dari kemiskinannya, sehingga pada saatnya, yang bersangkutan dapat berubah dari mustahik menjadi muzakki atau minimal mutashaddiq. Zakat adalah salah satu ibadah dalam Islam yang berdimensi spritual personal, sosial dan ekonomi. Dalam tinjauan ekonomi, zakat adalah instrumen utama kebijakan fiskal negara guna mendistribusikan kekayaan dan kesejahteraan yang berkeadilan. Oleh karena itu, mekanisme manajemen pengelolaan harus mendapat perhatian serius. Pengelola zakat harus mampu

${ }^{18}$ Mansur Efendi, Paradigma Baru Manajemen Zakat Dalam Pengentasan Kemiskinan Di Indonesia, Urgensi dan Konsep Pemberdayaan dalam Pengelolaan Zakat, jurnal ilmu syariah al-ahkam, vol 9, no. 2, september 2011 
mengemban amanah mewujudkan potensi zakat yang luar biasa, terutama di Indonesia. 


\section{DAFTAR PUSTAKA}

Badriadi, Lili et.al, Zakat dan Wirausaha, 2005 Jakarta: CED.

Departemen Agama RI Dirjen Bimas Islam Direktorat Pemberdayaan Zakat, 2008, Panduan Organisasi Pengelola Zakat, Jakarta: Depag.

Hafiduddin, Didin dan Hendri Tanjung, 2003, Manajemen Syariah dalam Praktik, Jakarta: GIP, cet.1.

Hafiduddin, Didin dan Ahmad Juwaini, 2007, Membangun Peradaban Zakat, Menuju Jalan Kegemilangan Zakat, Cet.1, Ciputat: IMZ.

Hafiduddin, Didin, 2006, Mutiara Dakwah : Mengupas Konsep Islam Tentang Ilmu, Harta, Zakat \& Ekonom Syari'ah, Jakarta : Kuwais.

Ismail, Asep Usman, 2012, Al-qur'an dan kesejahteraan sosial, Tangerang: Lentera Hati.

Mansur Efendi, Paradigma Baru Manajemen Zakat Dalam Pengentasan Kemiskinan Di Indonesia, Urgensi dan Konsep Pemberdayaan dalam Pengelolaan Zakat, Jurnal Ilmu Syariah Al-Ahkam, vol 9, no. 2, September 2011.

Muhammad Firdaus, Irfan Syauqi Beik, Tonny Irawan, Bambang Juanda, Econom ic Estimation and Determinations of Zakat Potential in Indonesia, IRTI.

Peraturan Menteri Dalam Negeri No 20 Tahun 2010.

Qaradhawi, Yusuf, 2005, Spektrum Zakat Dalam Membangun Ekonomi Kerakyatan, Jakarta: Zikrul Hakim.

Solihin, Model Pemberdayaan Ekonomi Masyarakat Melalui Pengelolaan Zakat, Infaq dan Shodaqah (ZIS) (Studi Pada Badan Amil Zakat Kota Malang)

Sudewo, Eri, 2012, Manajemen ZIS, Ciputat: IMZ, cet 1.

Sudirman, 2007, Zakat Dalam Pusaran Arus Modernitas, Malang: UIN Malang Press.

Tim Institut Manajemen Zakat, 2006, Profil 7 Bazda Propinsi \& Kabupaten Potensial, Ciputat: Institut Manajemen Zakat cet 1. 
Tim penulis IZDR, 2011, Menggagas Arsitektur Zakat Indonesia: Menuju Sinergi Pemerintah Dan Masyarakat Sipil Dalam Pengelolaan Zakat Nasional, Ciputat: IMZ, cet 2.

www.damandiri.or.id. 